\title{
DIGITAL TECHNOLOGY AS SUPPORT OF COGNITIVE PROCESSES OF PEOPLE WITH VISUAL IMPAIRMENTS
}

\author{
Gabriela Spinarova \\ Palacky University in Olomouc, Czech Republic \\ Veronika Vachalova \\ Palacky University in Olomouc, Czech Republic
}

\begin{abstract}
At present, we increasingly encounter the concept of so-called digital literacy. Digital technologies are constantly evolving in this field and play an important role in human life. They are important not only in the labor market but also in education and human skills development. Digital technologies are thus one of the means by which we can develop the cognitive processes of visually impaired people. We can thus help them to improve a number of areas that are limited due to loss or reduction of visual perception. Especially, thinking, memory, and creating ideas are very important. This contribution was created within the solution of the project $T A C L$ - Reduction of information deficit and development of the imagination of visually impaired people through 3D models with auditory elements in cooperation with the project PIGŽU - Support of information literacy of pupils and teachers. The first of the projects aims to reduce the information deficit caused by the loss or reduction of visual perception in visually impaired people using multisensory action. At the same time, it aims to develop their spatial imagination. The second project then focus on the creation of digital aids, which aims primarily at the development and support of computational thinking. In addition to mainstream primary school pupils, the project also focuses on pupils with special educational needs, including visually impaired individuals. The main output of the project is the creation of aids, including methodologies, using digital technologies. These are technologies such as Ozobot, Blue-Bot, or Bee-bot. The aim of the paper is to acquaint with the project, to provide at least basic information about digital technologies, and especially to describe the possibilities of personality development, skills, and abilities using these technologies in visually impaired students.
\end{abstract}

Keywords: cognitive processes, digital technologies, visual impairment.

\section{Introduction}

The present time in history is clearly associated with digital technologies. The number of these technologies is constantly growing and evolving. They are an integral part of human existence. Most of us use digital technologies for game play or other personal entertainment. However, they are also a means of sharing and obtaining information and communicating with each other. Digital 
Spinarova \& Vachalova, 2021. Digital Technology as Support of Cognitive Processes of People with Visual Impairments

technologies and changing society and are creating new demands on individuals. It is therefore clear that if a person wants to be an active, modern, technically proficient, online individual, he must be provided with the means to achieve a sufficient and quality skill set in this area. At the same time, he should be fully aware of their pros and cons. In other words, we are talking about digital literacy.

Modern digital technologies can also help us in education. They represent one of the ways to streamline the learning and development of pupils with visual impairment. We perceive as a significant positive that digital technologies can have a motivational aspect for a pupil with visual impairment. The teaching of visually impaired pupils is also based on the development of cognitive processes. The teacher should recognize the importance of individual cognitive processes when working with all pupils, and in particular, should be aware, that a visually impaired pupil will use them in a different way than a pupil without a disability. At the same time, it is important to realize that each student's possibilities, abilities and level of cognitive processes are completely individual. The main goal of this paper is not only the presentation of individual projects and digital technologies, but above all, the presentation of examples of educational materials for visually impaired pupils using robotic educational tools.

Digital literacy

„Digital literacy is a set of individual (digital) competencies that an individual needs for the safe, confident, critical and creative use of digital technologies at work, in learning, in leisure time and in their involvement in social life.“ (DIGIFOLIO: Digitální gramotnost, 2020).

An individual's digital literacy can develop in several ways. The first is through informal learning at the individual level. That is, gaining new knowledge individually, based on their own skills and, needs and their own pace. However, even in this case, we often encounter other possible development supports, either through informal communities such as family, friends, interest groups, etc. or through formalized education, which is conducted by professionals within a school setting or in official courses. Each of these forms of digital literacy development has its advantages and disadvantages. One of the acceptable variants is the possibility of connecting the given forms so that they are motivating for the individual and at the same time bring him such an education that is identical in content with his real needs (MPSV, 2015).

DigComp (2019) identified five areas of competence that are essential for the development of digital literacy. The first is information and data literacy. Here, the individual should be able to work with data, be able to search, filter, but also evaluate and manage other information and digital content. The second area is then communication and cooperation. Further areas are the creation of digital content, security and problem solving (DIGCOMP 2.1., 2019). 
The great potential of digital technologies lies mainly in the field of education. There are opportunities for the development and training of new skills or cognitive processes. If we know how to use digital technologies in teaching, we gain a path toward more effective and quality teaching or home preparation for it. However, it remains true that these technologies are aids for the teacher to utilize together with his pupils. That is, they do not replace his work (Kopecký et al., 2021).

People with visual impairment and specifics in cognitive processes. People obtain a striking amount of information from the surrounding world through visual input - up to $85 \%$ (Robb, 2003). However, in the case of visually impaired people, this process is weakened or completely blocked, and therefore it is necessary to focus more attention on this group in many respects and to particularly heed problem areas (Codding, 1984). In addition to a physical disadvantage, the disability brings with it many secondary complications in the mental and social spheres. These include, for example, establishing social contacts, difficulty gaining employment in the labor market, problems in the field of self-care activities, independent movement or orientation, or difficult daily activities. The area of information acquisition and learning is also greatly affected. Learning and support in acquiring new skills and knowledge is thus one of the main means of supporting the development of a visually impaired child (LaVenture \& Allman, 2007).

In addition to the development of lower compensatory factors (hearing, touch, smell and taste), we must not neglect higher compensatory factors, that is, individual cognitive processes. Attention and concentration are essential in the daily activities of a visually impaired person. In addition to deliberately concentrating on work or a task (eg at school), they are also relevant to perceiving and concentrating on one's own body and, its position in space, and therefore these factors are significant in the spatial orientation and independent movement of the individual. According to Vágnerová (2004), a serious visual impairment will affect the development of cognitive processes, especially in children with congenital disabilities. However, it is important to realize that this deficit in cognitive processes can be largely offset with rehabilitative and educational support (Růžičcková \& Vítová, 2014).

We consider tactile perception in cooperation with other senses to be the primary means of sensory input in a person with severe visual impairment. Unlike auditory perception, it allows the creation of specific ideas about a twodimensional image or a three-dimensional object. Tactile perception differs qualitatively and quantitatively from visual perception. Tactile perception is more time consuming and concentration is required. Tactile memory and thinking are also used here (Janková \& Moravcová, 2017; Růžičková \& Vítová, 2014). 
Spinarova \& Vachalova, 2021. Digital Technology as Support of Cognitive Processes of People with Visual Impairments

Attention is a function of consciousness that allows selective selection of stimuli. The selection of stimuli may be different in the case of limited visual perception. Attention is more easily attracted by new, but at least partially understandable stimuli. In the case of visually impaired people, these will be stimuli that are at least partially understandable and perceptually distinguishable (Vágnerová, 2004).

The development of thinking in people with visual impairments is very similar to its development in people without disabilities, but it differs in some respects. The loss of visual functions is reflected in the form of perception that is related to the thinking of a particular person. However, visual impairment results in lower CNS (central nervous system) activation (Balunová, Heřmánková \& Ludíková, 2001). Problems can arise when recognizing objects and finding their same features, comparing them, or generalizing to a greater degree (Požár, 2000). Vágnerová (2004) states that in visually impaired people, the development of thinking is more closely associated with the development of speech. In addition to communication and cognitive functions, we can also talk about the compensatory function. The level of verbal intelligence is not directly dependent on visual impairment. Here we can encounter discussion about the use of so-called 'verbalisms', words or phrases which are not grounded in direct sensory experience. The claim has been that visually impaired people may not precisely understand the meaning of these expressions.

Of course, limited visual perception also affects the creation of images. Although tactile perception can largely compensate for visual perception, visually impaired persons will have different images, both qualitatively and quantitatively, than people without disabilities. Typical features of the creation of images of people with visual impairment are: fragility, schematism, low generalization and use of verbalism (Litvak, 1979).

The memory of a visually impaired person must be constantly activated and burdened. What a person without a disability can recognize at first sight must often be remembered by the visually impaired (eg the layout of clothes in the closet, the dishes on the kitchen shelf, etc.) (Kudelová \& Květoňová-Švecová, 1996). In this way, the mind retains a large amount of important information, which it uses not only in everyday activities, but also in further learning. Partially sighted people prefer use of sight in learning new things, as it will allow the building of visual memory and the creation of the most accurate visual images. In the case of blind people, compensatory means and substitution are used. The application of a multisensory approach is essential for the education of visually impaired people. Auditory memory is more important for people with severe visual impairments. Obtaining different information from the environment is often more difficult than keeping it. Therefore, visually impaired people are largely reliant on auditory memory. Tactile memory is also used. In contrast, 
people without disabilities hardly use it. Therefore, these memory abilities can be better developed in visually impaired people due to their specific life situation (Vágnerová, 2004).

\section{Projects}

This paper is based on two projects. The first is TAČR - Reduction of information deficit and development of the imagination of visually impaired people through 3D models with auditory elements. The primary goal of the project is to reduce the information deficit caused by the loss or reduction of visual perception in people with visual impairment, while at the same time developing their spatial imagination, through the use of multisensory activities. This will be achieved specifically through the design, creation, and practical implementation of 3D audio-tactile models of historical and religious monuments. These models will be used in working with the target group of users and will also be available to operators of selected monuments for the general public. As follows from the above, the project also fundamentally combines the technical and non-technical content of research. The use of TouchIt3D technology, which was established at the Department of Geoinformatics at Palacky University in Olomouc (Czech Republic), is essential for the implementation of the proposed 3D models. The target group includes people with visual impairments and with the age spectrum across different types and degrees of visual impairment. The outputs of the project are aimed at increasing the quality of life of visually impaired people in public spaces.

PIGŽU project - Support of information literacy of pupils and teachers. It focuses on supporting the creation of digital teaching aids aimed at the development and support of digital skills in the primary school environment. Above all, it is the preparation of aids to support teaching through robotic educational tools, mobile touch devices and augmented reality systems. The project outputs will also include methodologies for the inclusion of individual technologies in teaching and homework. The main goal of the project is to create and verify sets of teaching materials and aids using digital technologies directly in teaching. As part of the project, schools will receive digital teaching aids that they can actively use in practice. The sets of materials and methodologies will be created for three target groups: primary school pupils (years 1-5), primary school pupils (years 6-9), and primary school pupils with special educational needs (years 1-5).

\section{Methodology}

For the needs of our article, we will focus mainly on sets of materials for visually impaired pupils in primary school. The sets of materials and methodologies that are created within the project focus on the development of 
Spinarova \& Vachalova, 2021. Digital Technology as Support of Cognitive Processes of People with Visual Impairments

imagination, mathematical and logical thinking about information. This primarily includes teaching aids for robotic programmable tools such as BlueBot and BeeBot. For visually impaired pupils, it will be tactile-adjusted „playgrounds“ (surfaces for the robots to operate on), and embossed and colored didactic cards both those that are commonly on the market and those that will be created as part of another area of these outputs. Playgrounds, as well as cards, will be adapted to the needs of visually impaired pupils. They will focus on the development of both imagination and mathematical and logical thinking. The focus of the work with the cards is the development of pupils' digital skills through problem-solving situations, or alternatively on the development of storytelling and narrative skills. The individual digital technologies used in the project are described below.

For our needs we work mainly with the following technologies:

BeeBot is an easily programmable robotic device. It looks like a bee - it has yellow and black stripes. Because of this contrast, Beebots are a suitable tool for working with visually impaired students. Among other things, they also look attractive to younger children. At the top of BeeBot, we find buttons with which we control it. The robot is also equipped with an audible signal of the buttons and as soon as it reaches the finish line it plays a short jingle. The bee is able to memorize up to 40 steps and moves ideally on a smooth surface with a square mat. This can be supplemented with any images. Anyone can easily make their own mats (Kopecký et al., 2021).

Ozobot is one of the most advanced programmable robotic aids. Ozobot can be quickly and easily programmed using drawing. Commands can be entered using color codes (so-called OzoCodes). You can also use the intuitive visual editor OzoBlockly. Ozobot can be easily connected to a tablet and controlled using a user-friendly application. This expands the potential of this device with many other elements. With the help of Ozobots, we can develop children's creativity, logic, and computational thinking. It is attractive and fun for pupils and teaches the basics of programming and robotics (Kopecký et al., 2021).

Other technologies such as BlueBot and MergeCube, (among others) can be used for this work.

In the following section, we will introduce you to the specific activities created in this project. Now a few sentences about their production.

To produce playgrounds for Ozobots, the program CorelDRAW Graphics Suite 2020 was used. With this software, any map on any topic can be created. A map created in this way can then be supplemented with suitable pictures/symbols. In this case, it is important to think about the appropriate location of the codes. Locations for placing color codes are shown by white squares (Fig.1). The pupils' task is to color these squares with suitable color OzoCodes (Fig. 2). Depending on the pupils' abilities, we can choose maps that are simpler with fewer OzoCodes 
or more complex, where we force the pupil to think more about which color combination to choose.

The playground in our second activity (Table 2) is made to measure from a wooden board (according to the template of the playground made of transparent plastic). The board is equipped with grooves for stops, which allow the pupils with visual impairment to better orientate themselves on the surface. Picture cards are made on a Fuser. They are thus haptically acceptable for visually impaired students. We also transferred the form of cards to 3D models using a 3D printer.

\section{Results}

In the tables below, you can see examples of activities for visually impaired pupils using robotic technologies. The first (Table 1) presents working with Ozobots. The activity called Contours focuses on the development of concentration and attention. Furthermore, the development of visual perception, together with logical and computational thinking, perceptual differentiation, and the ability to perceive the integrity of contours. The second (Table 2) then represents the activity using BeeBot. However, this robotic toy can also be fully represented by its BlueBot double. Based on the programming of this tool, we develop in students not only visual and tactile perception but again logical and computational thinking, memory, spatial orientation, and algorithmic thinking. A more detailed description of the activities is shown in the tables (Table 1, Table 2). The first of the tables (Table 1) is also supplemented by a picture of the map - the playground (Fig.1), which the pupils will work with.

\section{Table 1 Activity to Work with Ozobot}

\begin{tabular}{|c|l|}
\hline \multicolumn{2}{|l|}{ CONTOURS } \\
\hline Focus & visually impaired pupils \\
\hline Aim & development of concentration, attention, visual perception \\
\hline Technology & Ozobot (OzoCode) \\
\hline $\begin{array}{c}\text { Activity } \\
\text { description }\end{array}$ & $\begin{array}{l}\text { The activity is based on a task or situation with a problem that pupils have to } \\
\text { solve. } \\
\text { The aim of the activity is to use the OzoCodes to complete the route so that the } \\
\text { robot reaches the goal. } \\
\text { The activity is primarily focused on the development of concentration and } \\
\text { attention, but also on visual perception, perceptual differentiation, and the ability } \\
\text { to perceive the integrity of the objects. }\end{array}$ \\
\hline Assignment & $\begin{array}{l}\text { We carry out the activity itself according to the abilities of the pupils. } \\
\text { 1. In the first step, we introduce pupils to how to program Ozobot + what } \\
\text { types of OzoCodes we have and what they mean. } \\
\text { 2. Before the pupils start working with the map on their own, it is advisable } \\
\text { to go through the individual pictures with them so that it is clear what } \\
\text { they represent. }\end{array}$ \\
\hline
\end{tabular}


Spinarova \& Vachalova, 2021. Digital Technology as Support of Cognitive Processes of People with Visual Impairments

\begin{tabular}{|c|l|}
\hline & $\begin{array}{l}\text { 3. The pupil's task is to recognize the image at the start and program the } \\
\text { Ozobot so as to finish at its contrasting variant. }\end{array}$ \\
\hline Solution & $\begin{array}{l}\text { Ozobot travels the route so that it stops at the picture (racket), which is a } \\
\text { contrasting variant of the picture at the start. }\end{array}$ \\
\hline
\end{tabular}

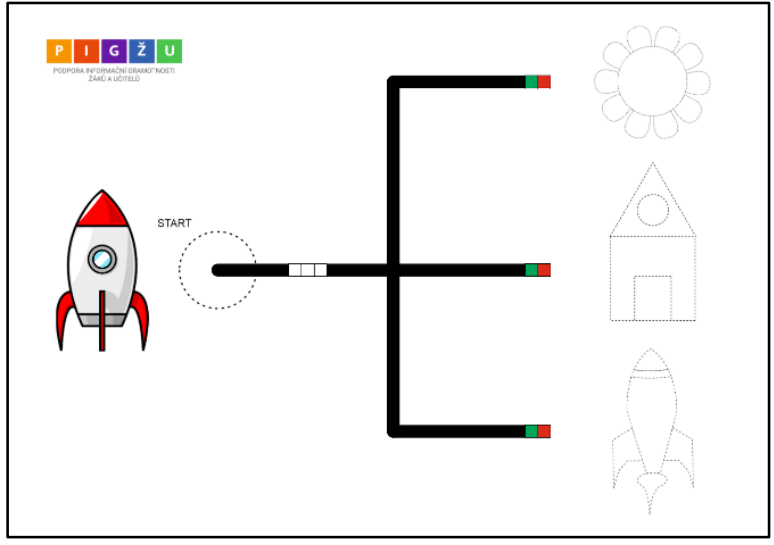

Figure 2 Map for Ozobot - not completed

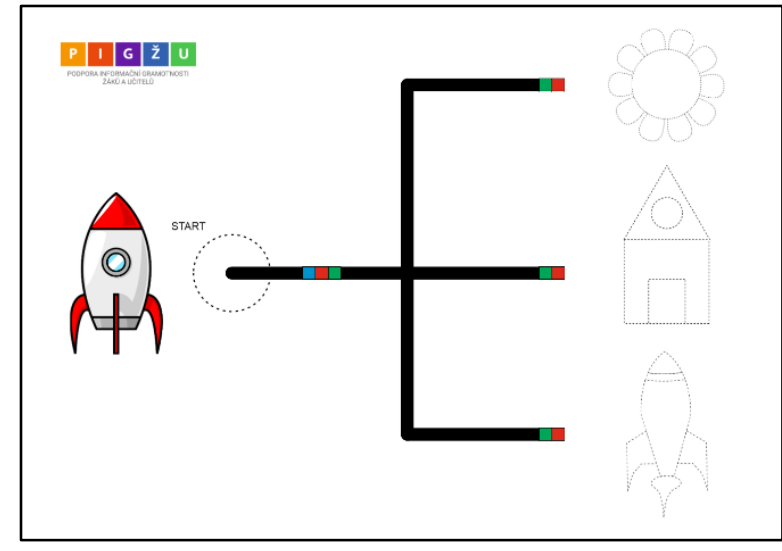

Figure 1 Map for Ozobot - completed

Table 2 Activity to Work with BeeBot

\begin{tabular}{|c|c|}
\hline \multicolumn{2}{|r|}{ JOURNEY THROUGH THE CITY } \\
\hline Focus & visually impaired pupils \\
\hline Aim & development of concentration, attention, visual and tactile perception \\
\hline Technology & BeeBot/BlueBot \\
\hline $\begin{array}{c}\text { Activity } \\
\text { description }\end{array}$ & $\begin{array}{l}\text { The activity is based on a task or situation with a problem that pupils have } \\
\text { to solve. } \\
\text { Thanks to the programming BeeBot/BlueBot, in addition to the } \\
\text { development of visual and tactile perception itself, pupils train logical } \\
\text { thinking, memory, spatial orientation, and algorithmic thinking. } \\
\text { We can use a standard transparent mat for BeeBot/BlueBot with a grid to } \\
\text { carry out the task. A more suitable alternative for visually impaired pupils } \\
\text { is a wooden board, with the same parameters as a transparent mat. } \\
\text { However, the board is equipped with grooves where the stops can be } \\
\text { inserted. The visually impaired pupil thus orients himself better on the } \\
\text { surface, thanks to the tactile support of the stops. } \\
\text { Images of buildings located in the city, printed on a Fuser, are also } \\
\text { available on the mat. More specifically: } \\
\text { - House } \\
\text { - School } \\
\text { - Apartment block } \\
\text { - Church } \\
\text { - Zoo } \\
\text { - Bakery } \\
\text { - Flower shop } \\
\text { - Butcher shop }\end{array}$ \\
\hline
\end{tabular}




\begin{tabular}{|l|l|}
\hline Assignment & $\begin{array}{l}\text { Scale 3D models of these buildings or objects representing them are also } \\
\text { available. The child can thus touch the models and better imagine their } \\
\text { appearance. } \\
\text { The aim of the activity is to program the robot to travel a predetermined } \\
\text { route or reach a specific destination in the city. }\end{array}$ \\
\hline $\begin{array}{l}\text { We carry out the activity itself according to the abilities of the pupils. } \\
\text { The teacher can work with several variants of the task. }\end{array}$ \\
$\begin{array}{l}\text { 1. Using images made on a Fuser } \\
\text { 2. Using 3D models }\end{array}$ \\
$\begin{array}{l}\text { Which routes will be chosen depends on the teacher. The task can be } \\
\text { simple - to get from point A to point B. The teacher can make the task } \\
\text { more difficult by giving the student 3 or more places, which passed } \\
\text { through in the correct order with the help of a robot. }\end{array}$ \\
\hline
\end{tabular}

\section{Conclusions}

Despite widespread discussion about the massive spread of technology to various areas of human life, the education of pupils and students with the aid of digital technologies is still underused in many respects. The application of digital technologies in teaching is associated with new procedures and methods and in relation to the good organizational skills of teachers. Above all, it is a motivation to learn something, new and, to then pass on this knowledge and the possibilities of a creative approach through the act of teaching. The teacher should lead his students to develop individual digital competencies. These are based on the above-mentioned competence areas of the European Framework of Digital Competences of Citizens - DigComp. These include information and media literacy, digital communication and collaboration, digital content creation, responsible use of digital technologies and problem solving through digital technologies (Redecker \& Punie, 2017).

At present in the project we are in the phase of production of educational materials using robotic digital technologies. The next phase will be the verification and possible modification of materials in schools. Within the article, our goal was to focus on the issue of digital technologies in the education of visually impaired pupils. At the same time, to aid in understanding, we added a few examples that can be used when teaching these pupils. 
Spinarova \& Vachalova, 2021. Digital Technology as Support of Cognitive Processes of People with Visual Impairments

\section{Acknowledgements}

The creation of this paper was funded by project TL03000679 Information deficit reduction and the development of imagination of persons with visual impairment through 3D models with auditory elements.

\section{References}

Balunová, K., Heřmánková, D. \& Ludíková, L. (2001). Kapitoly z rané výchovy dítěte se zrakovým postižením. Olomouc: Univerzita Palackého. (Czech language)

DIGIFOLIO. (2020). Digitální gramotnost. Metodický portál RVP.cz. Retrieved from https://digifolio.rvp.cz/view/view.php?id=13123\&rate=5 (Czech language)

DIGCOMP 2.1. (2019). Rámec digitálních kompetencí pro občany. DigiKatalog vzdělávání zaměstnavatelì a zaměstnancư voblasti digitálních kompetencí. Retrieved from https://portaldigi.cz/ (Czech language)

Codding, P. (1984). Music therapy for visually impaired children. In W. B. Lathom \& C. T. Eagle (Eds.), Music therapy for handicapped children. Volume I: For the hearing impaired, visually impaired, deaf-blind (pp. 43-96).

Janková, J., \& Moravcová, D. (2017). Asistent pedagoga a ditě se zrakovým postižením. Praha: Pasparta. (Czech language)

Kopecký, K., Szotkowski, R., Kubala, L., Krejčí, V. \& Havelka, M. (2021). Moderní technologie ve výuce: o moderních technologiích ve výuce s pedagogy pro pedagogy. Olomouc: Pedagogická fakulta Univerzity Palackého v Olomouci. (Czech language)

Kudelová, I., \& Květoňová-Švecová, L. (1996). Malé ditě s těžkým poškozením zraku: raná péče o ditě se zrakovým a kombinovaným postižením. Brno: Paido. (Czech language)

LaVenture, S., \& Allman, C. (2007). Special education services: What parents need to know. In S. LaVenture (Ed.), A parents' guide to special education for children with visual impairments (pp. 3-35).

Litvak, A.G. (1979). Nástin psychologie nevidomých a slabozrakých. Praha: SPN. (Czech language)

MPSV. (2015). Strategie digitální gramotnosti $\check{C} R$ 2015-2020. Retrieved from https://www.mpsv.cz/web/cz/strategie-digitalni-gramotnosti-cr (Czech language)

Požár, L. (2000). Psychológia detí a mládeže s poruchami zraku. Trnava: Trnavská univerzita. (Slovak language)

Redecker, Ch., \& Punie, Y. (2017). European Framework for the Digital Competence of Educators: DigCompEdu. European union. Retrieved from https://ec.europa.eu/jrc/en/ publication/eur-scientific-and-technical-research-reports/european-framework-digitalcompetence-educators-digcompedu

Robb, S. (2003). Music interventions and group participation skills of preschoolers with visual impairments: Raising questions about music, arousal, and attention. Journal of Music Therapy, 40(4), 266-282.

Růžičková, K. \& Vítová, J. (2014). Vybrané kapitoly z tyflopedie a surdopedie nejen pro speciální pedagogy. Hradec Králové: Gaudeamus. (Czech language)

Vágnerová, M. (2004). Psychopatologie pro pomáhající profese. Praha: Portál. (Czech language) 